\title{
A BÜNTETÉS-VÉGREHAJTÁS ÉS A MAGÁNSZFÉRA*
}

\author{
Varga Judit ${ }^{l}$
}

A rendészeti tevékenység alapvetöen közjogi szabályozás és eszközök formájában ölt testet, de néhány speciális helyzetben a magánszféra is megjelenik mind a közszolgáltatás keresleti, illetve kinálati oldalán. Mint ahogy Madai Sándor is utal rá tanulmányában $^{2}$ a rendészeti tevékenységhez kapcsolódóan beszélhetünk a PPP-röl, ${ }^{3}$ azaz a köz és magán szektor együttmüködéséről, mely a büntetés-végrehajtás területén is megjelenik. A modern büntetés-végrehajtási intézeteknek hármas funkciója van. Feladatuk megvédeni a társadalom tagjait a közösség jogot megsértö elemeitöl, büntetni a jogsértőket és biztositani azok jövőbeli társadalomba integrálását. ${ }^{4}$ A kontinentális jogi hagyományokkal rendelkezö államokban a büntetés-végrehajtási intézetek föszabály szerint állami tulajdonban és fenntartásban állnak, ám a PPP formában létrejövö büntetés-végrehajtási intézetekre, mint a börtönprivatizáció modernkori alakváltozataira elöbbi államokban is találni példát. ${ }^{5}$

Hazánkban büntetés-végrehajtási területen az új büntetés-végrehajtási intézetek létesitéséröl, valamint a beruházásokhoz kötödö forrásbevonásról szóló 2126/2004. (V. 28.) Korm. határozat teremtett módot a PPP applikálására. A Kormány két, egyenként 700 új féröhelyet biztosító börtön és fegyház fokozatú intézet alapításáról rendelkezett, amelyek kö zül egy az ország északkeleti térségében (Tiszalök), egy a nyu gati régióban (Szo mbathely) létesült költségvetési és költségvetésen kívüli források felhasználásával. Az intézetek DBFO (design-build-operate-finance) konstrukció formájában létesültek, átadásukra 2008-ban került sor.

Az intézmények szervezeti és mű ködési szabályzataiból, látható, hogy a szerződéses partnerek feladatelosztása hasonló módon alakult. A közszektor alanya tartozott felelősséggel a felnőtt férfi elítéltek fegyház, börtön és kivételesen fogház fokozatú szabadságvesztésével, valamint az előzetesen nem jogerősen elítéltek fogva tartásával összefüggő büntetés-végrehajtási feladatok ellátásáért. A magánszektorbeli szereplö pedig olyan teendők elvégzéséért állt helyt, mint az ingatlan müszaki, gondnoksági üzemeltetése, az állagvédelemmel összefüggő munkák elvégzése, a fogvatartotti állomány ruházattal, felszerelési tárgyakkal való ellátása, mosatási teendők, telekommunikációs és informatikai szolgáltatások, a takarítási feladatok, fogvatartottak

\footnotetext{
${ }^{*}$ DOI 10.21867/KjK/2016.5.7.

${ }^{1}$ Varga Judit, egyetemi tanársegéd, DE-ÁJK

${ }^{2}$ Madai Sándor: Közhatalmi és szolgáltatási szerepek - keveredés?

3 A kérdéskört lásd részletesebben: Varga Judit: A partnerség (PPP) szerepének változása a közpénzügyek jogában, PhD Értekezés, DE Marton Géza Állam- és Jogtudományi Doktori Iskola, Debrecen, 2016.

${ }^{4}$ Cabral, Sandro - Saussier, Stéphane, Organizing Prison through Public-Private Partnerships: A Cross-Country Investigation, ANPAD \& BAR, 2012, 6. Forrás: http://www. scielo.br/scielo.php?pid=S1 807-76922013000100007\&script=sci_arttext\&tlng=es (2015.09.22.)

5 Mason, Cody, International Growth Trends in Prison Privatisation, 2013, 1. Forrás: http://sentencingproject.org/doc/publications/inc_International\%20Growth\%20T rends\%20in\%20Prison \%20Privatization.pdf (2015.09.22.)
} 
élelmezése és így tovább. Tehát minden olyan tevékenység, amely a fogvatartottak felügyeletén, örizetén kívül esik, a magánpartnernél csapódott le. A vállalkozók kötelesek voltak gondoskodni arról, hogy az intézet létesítményei, berendezései, technikai eszközei üzemképes állapotban a büntetés-végrehajtási feladatok ellátására folyamatosan rendelkezésre álljanak. A megjelölt üzemeltetői feladatok szerződésen alapuló szolgáltatásoknak minősültek, ezért a bérbeadói-szolgáltatási tevékenységet folyamatosan figyelemmel kísérték, az esetlegesen előforduló hibákat, vagy a nem megfelelő teljesítést szankcionálták, amely legin kább a monitoring keretében felépített pontozásos rendszer segítségével megállapított szolgáltatási díjcsökkentésben öltött testet.

A két intézmény között alapvető különbség a tulajdonosi helyzetükben volt. A tiszalöki épület a magánpartner tulajdonában állt, a földterületre vonatkozóan pedig haszonélvezeti jogot kapott a magánfél. A szerződési idő végén a felek megállapodásától függően került volna állami tulajdonba az épület. Ezzel ellentétben a szombathelyi intézet a kivitelezés és a müködés ideje alatt állami tulajdonban volt, ám azon a magánvállalkozó számára haszonélvezeti jogot létesítettek. A szerződés ideje alatt is már az állam a magánválla lko zó számára e jogcím alapján fizetett bérleti dijat az intézmény has ználatáért.

\section{Defektusok a PPP hazai alkalmazásában}

A büntetés-végrehajtási infrastruktúra fejlesztésére megkötött PPP szerződéseknél problémát jelentett a konzisztens joganyag hiánya. Kontinentális jogi hagyományokkal rendelkező állam lévén ráadásul adaptációs nehézségekkel is szembe kellett néznünk. Ezek a problémák már az előkészítés fázisában kihívást jelentettek. A PPP alkalmazását lehetővé tevő joganyag megalkotása, annak véglegessé válása, az említett projektek előkészítése, adott esetben kivitelezése egymással párhuzamosan folyt hazánkban, illetve a 2007-re teljessé váló PPP normatömeg jogrendszerünkben szétszórva volt megtalálható, mely körülmény a jogkövetést terhes ebbé tette. ${ }^{6}$

A magánszektorbeli alanyok profitorientált szemléletéből fakadó nehézségekkel az itthoni intézeteknek is szembesülniük kellett az üzemeltetés során. Az elítéltek étkeztetésének biztosítása körül keletkezett a legtöbb konfliktus. Egyrészt azért, mert az étkeztetés biztosításáért felelős vállalkozó komolyabb összegeket volt képes megtakarítani ezen a területen. A rosszabb minőségü, olcsóbb étel a rabok részéről ellenállást szült, melyből fakadó elégedetlenség kezelése a hivatásos állo mányra hárult. Ráadásul Tiszalökön például gondot jelentett az étkeztetést biztosító vállalkozó szankcionálása a fővállalkozó által, hisz e két szereplő között nem volt kapcsolat. A fővállalkozó kötött szerződést annak idején a magyar állam képviselőjével, az ő kötelezettsége volt a szerződés teljesítése, ugyanakkor a helyszínen nem ő, hanem leányvállalata volt jelen (itt: Szent Adorján Kft.), aki az üzemeltetési feladatok ellátásáért felelt. Az étkezetés biztosítását ebben a büntetés-végrehajtási intézetben azonban nem kö zvetlenül az üzemeltető kft. végezte, hanem egy alvállalkozó, akivel a Szent Adorján Kft. állt szerződéses viszonyban. A fővállalkozónak így nem voltak

\footnotetext{
${ }^{6}$ KISS Ágnes Katalin, A PPP-konstrukcióban megvalósuló bv. intézetek gazdasági keretrendszere. In: Börtönügyi Szemle, 2007, 26. évf., 4. sz., 35-36.
} 
megfelelő eszközei arra, hogy a rabok étkeztetéséért felelős alvállalkozót a szerződés teljesítésére kényszerítse. ${ }^{7}$

Nem túl s zerencsés továbbá, hogy a PPP formában múködő intézetek üzemeltetői nem voltak kötelezve a fogvatartottak munkáltatására. A nem PPP konstrukcióban létesült büntetés-végrehajtási egységek érdekeltek a rabok foglalkoztatásában, hisz a dolgozó elítéltek keres ményükből hozzájárultak tartásukhoz, az így befolyó összegek pedig az intézet kasszáját gyarapítják. A PPP börtönök esetén azonban az üzemeltető gondoskodott a fogvatartottak foglalkoztatásának biztosításáról, egy meghatározott létszámkeret erejéig erre kötelezettséget vállalt, azonban e fölött már nem volt érdekelt a munkalehetőség nyújtásában, hisz a rabok keres ményéből a tartásukra levont összegek nem nála, hanem az intézetnél jelentkeztek (illetve jelentkeztek volna) bevételként. ${ }^{8}$ A kialakuló helyzet két káros következménnyel is járt. Egyrés zt nem éltek az elítéltek tartásával összefüggő költségek csökkentésének egyik lehetőségével, ezzel sem törekedve a közpénzek hatékony felhasználására. Más részt a rabok foglalkoztatása nem elhanyagolható pozitív hatást gyakorol az intézeti rend és fegyelem megörzésére, s ily módon az üzemeltető és intézet közötti együttmüködés egyik lehetősége nem került alka lmazás ra.

\section{A börtönprivatizáció mellett és ellen szóló ér vek}

A büntetés-végrehajtási feladatok kiszervezése mellett szóló érvek a költséghatékonysághoz és az (esetlegesen) javuló szolgáltatási minöséghez kapcsolódnak.

A költséghatékonysággal hozhatók összefüggésbe, hogy a gazdasági profitra törekvő szolgáltatásnyújtók saját hasznuk maximalizálását célozzák, s előbbi érdekében, ahol tudnak, minimalizálják a felmerülő költségeket. Ez a fajta költség-racionalizáció különösen az infrastrukturális beruházások kivitelezése során, a munkabérek és a bürokrácia leépítésében figyelhető meg. A z állam számára pedig - az irányadó, hatályos szabályozás fényében - a szóban forgó közfeladatot kielégítő gazdasági társaságok potenciális adóbevételt is jelenthetnek. ${ }^{9}$

A közfeladat ellátás minőségének változása, mely, ha pozitív irányú, szintén felhozható érvként a börtönprivatizáció mellett. Kedvező irányú változás e téren a különböző büntetés-végrehajtási intézetekben nyújtott szolgáltatási színvonal javulása, vagy új programok, illetve a meglévők bővítése, fejlesztése, a fogvatartottak és persze a börtönszemélyzet biztonságának fokozása, valamint a büntetés-végrehajtási intézetekre jellemző túlzsúfoltság mérséklése.

\footnotetext{
${ }^{7}$ Interjú, 2012.09.20.

${ }^{8}$ Interjú, 2012.09.20.

${ }^{9}$ Lundahl, Brad - Kunz, Chelsea - Brownell, Cyndi - Harris, Norma - Van Vleet, Russ, Prison Privatization: A Meta-Analysis of Cost Effectiveness and Qulaity of Confinement Indicators, Utah Criminal Justice Center, College of Social Work, Unicersity of Utah, 2007, 29-30. Forrás: http://www.privateprisonnews.org/media/publications/utah_criminal_justice_center_college_of_social_ work_private_prison_analysis_2007.pdf (2015.09.22.)
} 
Persze nemcsak mellette, hanem a magánszektor bevonása ellen is felhozhatók érvek. Mindenekelött a felmerülö etikai konfliktusokat ${ }^{10}$ érdemes kiemelni. Visszásan hat, ha olyan állami feladatok ellátását, melyek alapvető emberi jogok korlátozásával járnak (profitérdekelt) gazdasági szereplöre bízzák. A közérdek szolgálatának célja mellett megjelennek, illetve akár dominánssá is válnak a profitérdekek. Itt említhető a közérdekű adatok nyilvánossága és az üzleti titkok védelme kapcsán jelentkező ellentét, mely abból fakad, hogy a közösségi szükségletek kielégítésére fordított közpénzek felhasználása közérdekből nyilvános, ám a pénzeket felhasználó szolgáltató üzleti titokra hivatkozással gyakran megtagadja a szóban forgó adatok nyilvánosságra hozatalát. Gyakran hozzák fel továbbá ellenérvként az erősödő lobbytevékenységet és az es etleges en ahhoz kapcsolódó korrupciót.

A különböző privatizációs megoldások szektorbeli alkalmazása ellen szóló érv a munkaerő állomány minőségének gyengülése, mely jelenti az állomány „minőségének” hanyatlását, s a végzett munka színvonalának gyengülését is. A szolgáltató profitérdekeltség okán végzett kiadáscsökkentése a munkabérekre hat, ami a munkabér, illetve az egyéb juttatások mérsékléséhez vezet. Az alacsonyabb munkabér a munkamorál süllyedésének és a jól képzett munkaerő távozásának irányába mutat. Megfigyelhető azonban a szakszervezetek gyengülése is, mely tovább súlyosbítja az előbb kibontott tendenciát.

Számos probléma adódhat abból is, hogy az állammal szerződő alany legtöbbször hosszú időtávra (5 vagy annál több év) vállalja el a feladatellátást. Ez azért problémás, mert a szerződés előkészítése során nem lehet valamennyi jövőbeli eseményt számba venni. A szolgáltató már a jelenben igyekszik a jövőben rejlő bizonytalanságokkal szemben úgy védekezni, hogy beárazza azokat, ami a szo lgáltatást megdrágítja. ${ }^{11}$

A bemutatott intézetek müködésében 2010 óta komoly változások feltételezhetők, egész konkrétan kivásárlásukra, államosításukra következtehetünk a költségvetési és zárszámadási törvényekböl. Azonban tény, hogy előbbi eseményekről, ahogy a szóban forgó büntetés-végrehajtási intézetek üzemeltetéséről sem állnak rendelkezésre konkrét adatsorok, azok nyilvános hozzáférése nem megoldott. A nyilvánosság tájékoztatásának korlátozása jelen esetben nem menthető, hisz a legtöbb büntetés-végrehajtási célt szolgáló intézet létesítése, fenntartása igen komoly költségvetési kiadást jelent, s mint ilyen, az itt jelentkező informác iók kö zérdekünek számítanak.

\footnotetext{
${ }^{10}$ Sekhonyane, Makubetse, The Pros and the Cons. Public-private partnerships (PPP) in South Africa prisons. In: SA Crime Quarterly, 2013, No. 3., March, pp. 35. Forrás: https://www.is safrica.org/uploa ds/7sekon.pdf (2015.09.23.)

${ }^{11}$ LUNDAHL - KUNZ - BROWNELL - HARRIS - VAN VLEET, i.m. 29-30.
} 